\title{
Morpho-Physiological Diversity in Arvi (Colocasia esculenta (L.) Schott. Var. Antiquorum)
}

\author{
A. K. Choudhary ${ }^{*}$, S. B. Mishra ${ }^{2}$, V. K. Choudhary ${ }^{2}$, Shanti Bhushan ${ }^{3}$ and A. K. Singh ${ }^{2}$ \\ ${ }^{1}$ Department of Plant Breeding \& Genetics, Bhola Paswan Shastri Agricultural College, \\ Purnea City, India \\ ${ }^{2}$ Department of Plant Breeding \& Genetics, Tirhut College of Agriculture (TCA), \\ Dholi, Muzaffarpur - 843 121, India \\ ${ }^{3}$ Department of Plant Breeding \& Genetics, VKSCOA (BAU, Sabour), \\ Dumraon-802136, Bihar, India \\ *Corresponding author
}

\begin{abstract}
A B S T R A C T
\section{Keywords}

Arvi, Selection

intensity,

Correlation

coefficient and

diversity

\section{Article Info}

Accepted:

26 May 2020

Available Online:

10 June 2020

The present investigation was conducted at Tirhut College of Agriculture (Bihar); without replication each plot measuring $1.5 \times 1.0$ meter in size and comprising 77 germplasm accessions. At 10 per cent selection intensity only 8 superior germplasm accessions including two check viz; C-29, UP-1, UP-3, C-1-92, C-6-92, White Gauria (LC), Jhingri and Shri Palavi (NC) were selected by combination of 10 quantitative traits with a certain range limits of each trait like plant size $(\mathrm{cm})$, leaf length :breadth ratio, leaf type (width) $(\mathrm{cm})$, petiole: leaf length ratio, petiole type, sheath type, corm size, cormel size and yield/plant. These accessions may be use full for further breeding programme. Petiole type exhibited significant and positive correlation with yield/plant $\left(0.277^{*}\right)$ while negative and highly significant correlation with sheath type $\left(-0.353^{* *}\right)$. Sheath type had negative and significant correlation with yield/plant ($\left.0.295^{*}\right)$ while significant and positive correlation was observed with Corm size $\left(0.234^{*}\right)$. Corm size recorded positive and highly significant correlation with yield/plant $\left(0.385^{* * *}\right)$. Selection based on these traits may be effective for further improvement programme of taro. Most of the accessions collected from different regions were placed in all cluster except for cluster VII and IX in which only one accession was found in each cluster from different region. Due to geographical diversity they may be placed in different cluster and indicates that they are not genetically identical with each other.
\end{abstract}

\section{Introduction}

Arvi (Colocasia esculenta (L.) Schott var. antiquorum) known as eddoe type or Taro or elephant ear belonging to the family Araceae, is one of the major crops grown in India (16) Cultivated ones are mostly diploid
$(2 \mathrm{n}=2 \mathrm{x}=28)$, although some triploids are found $(2 n=3 x=42)$. This staple crop is grown in tropical and subtropical countries and is consumed by over 400 million people worldwide (6). It is a good source of starch (70-80 g/100 g dry taro), fiber $(0.8 \%)$, and ash $(1.2 \%)$. 
Taro is also a good source of thiamine, riboflavin, iron, phosphorus, and zinc and a very good source of vitamin B6, vitamin C, niacin, potassium, copper, and manganese (13). Germplasm characterization and evaluation address the existing genetic variability that provides basic information towards improving the genetic makeup of crop plant.

Genetic variability is an essential and prerequisite for crop improvement program for obtaining high yielding genotypes. Therefore, knowledge of characterization and genetic variability is useful in formulation of effective selection strategy in breeding programme. The main objectives of this finding for characterization and evaluation of collected Colocasia esculenta (L.) Schott var. antiquorum edible accessions and to analyse its genetic diversity with the help of descriptors of NBPGR.

\section{Materials and Methods}

The present investigation was conducted at Tirhut College of Agriculture (Bihar); without replication each plot measuring $1.5 \times 1.0$ meter in size and comprising 77 germplasm accessions. The row to row distance was kept at $50 \mathrm{~cm}$ while plant

to plant distance was maintained at $30 \mathrm{~cm}$. The cormels were planted on the ridges in the month of March. Data were recorded with help of descriptor of NBPGR on the basis of five randomly selected plants at the maximum growth stage. The qualitative traits were recorded in the form of code which is assigned to each trait while, quantitative traits in numerical value and created 10 per cent selection intensity for the selection of elite genotypes by combining different traits with each other on certain limits viz;. plant size (70-95 cm), leaf length: breadth Ratio $(0.70$ 2.73), leaf type (width) (15-38.66), petiole: leaf length ratio(0.50-1.40), petiole type (30$45 \mathrm{~cm})$, sheath type $(14-28.33 \mathrm{~cm})$, corm size $(5-10.33 \mathrm{~cm})$, cormel size $(7-15 \mathrm{~cm})$ and cormel yield per plant (0.20-0.60kg).

All qualitative traits were categorized in different grouped based on frequency distribution of germplasm in the excel software and diversity analysis in SPSS software. Correlation - coefficient analysis were performed by using online OP stat.

\section{Results and Discussion}

\section{Frequency distribution of major qualitative traits}

\section{Vegetative characters}

Morpho-physiological characterization of 77 taro germplasm can be done based on its growth habit, type of stem, tillering, leaf arrangement, lamina orientation, leaf margin, leaf color, sinus colour, floral formation, corm characters, and other, quantitative traits helps in effective utilization of germplasm in crop improvement programmes.

Wide range of genetic variability were observed for morpho-physiological characters like leaf arrangement, lamina orientation, leaf margin, leaf margin colour, leaf colour upper (U), leaf colour lower (L), sinus colour, vein colour upper, vein colour lower, petiole colour top $1 / 3$ of the length, petiole colour middle of the length, petiole colour base of the length, leaf sheath pattern and leaf sheath colour whereas, no variation were observed for traits viz; leaf variegation and floral formation (Table 1 to 2).

Morpho-physiological traits may also be contributed maximum to the variation among the cultivars and can be used as minimum descriptors for characterizing the Arvi germplasm. 


\section{Leaf characteristics}

Among the eleven phenotypic classes of this trait frequency distribution were varied from $0-94.81 \%$ and none of the accessions had recorded green color for characters leaf colour lower (L) and sinus colour while, maximum frequency distribution exhibited $94.81 \%$ representing 73 accessions for traits leaf margin having Entire (Em) margin followed by leaf colour lower (L) $93.51 \%$ that represent 72 accessions which is characterized by light green. However, no variation was recorded for the trait i.e leaf variegation (Table 1).

\section{Petiole and leaf sheath characteristics}

Based on petiole and leaf sheath characters these traits were divided into five distinct classes based on their colour and pattern (Table 3). For traits petiole colour base of the length and petiole colour top $1 / 3$ of the length $88.31 \%$ and $67.53 \%$ accessions respectively were exhibited green colour each.

However, for the trait leaf sheath pattern $76.62 \%$ accessions were exhibited open sheath and rest of the accessions had closed sheath. For the character leaf sheath colour; $76.62 \%$ of the accessions exhibited green followed by $11.69 \%$ of the accessions exhibited purple colour.

Flower formation, seed formation and maturity

There are wide range of variability were exhibited among 77 accessions of taro for traits flower formation, seed formation and maturity (Table 2). Above $72.00 \%$ accessions had non-flowering (NF) character followed by $27.27 \%$ accessions were exhibited flowering (F) behaviour. However, for trait seed formation none of the germplasm was found to set the seed. Early maturity was observed in $81.82 \%$ of the accessions and $18.18 \%$ Normal maturity.

\section{Variation in quantitative traits}

Out of 77 accessions only eight superior lines viz, (C-29, UP-1, UP-3, C-1-92,C-6-92, White Gauria (LC), Jhingri and Shri Palavi (NC) were selected at 10 per cent selection intensity by fixing the certain limits of each quantitative traits viz; plant size (70.00-95.00 $\mathrm{cm})$, leaf length :breadth Ratio (0.70-2.73), leaf type (width) $(15.00-38.66 \mathrm{~cm})$, petiole: leaf length ratio (0.50-1.40), petiole type $(28.00-45.00 \mathrm{~cm})$, sheath type $(14.00-28.33$ $\mathrm{cm})$, Corm size (5.00-10.33), cormel size $(7.00-15.00 \mathrm{~cm})$ and yield/plant $(0.20-0.60$ $\mathrm{kg}$ ) (Table 3). All selected line were exhibited green petiole colour and comes under the selection group while none of the accession were fall under this group which were exhibited petiole colour green purple and purple.

Correlation coefficient is a statistical measure to determine the extent of association, whether positive or negative, between various plant characters and thus, helps to identify the character on which selection can be imposed for improvement in associated characters (Table 4). Plant size exhibited positive and highly significant correlation with Petiole type $\left(0.296^{* *}\right)$ and yield/plant $\left(0.407^{* *}\right)$ while negative and highly significant correlation were found with Leaf length:Breadth Ratio ($\left.0.367^{* *}\right)$. The results also showed that Leaf length:breadth ratio had strong highly significant correlation with corm size $\left(0.308^{* * *}\right)$ whereas negative and highly significant correlation were exhibited with leaf type $\left(-0.388^{* * *}\right)$ and Petiole type $\left(-0.297^{* *}\right)$. Leaf type had significant and positive correlation with cormel size $\left(0.231^{*}\right)$ as well as yield/plant $\left(0.292^{*}\right)$. Petiole: leaf length ratio significant and positive correlation with yield/plant $\left(0.259^{*}\right)$ whereas negative and 
highly significant correlation was found with Petiole type $\left(-0.344^{* *}\right)$. Petiole type exhibited significant and positive correlation with yield/plant $\left(0.277^{*}\right)$ while negative and highly significant correlation with sheath type ($\left.0.353^{* *}\right)$. Sheath type had negative and significant correlation with yield/plant ($0.295^{*}$ ) while significant and positive correlation was observed with Corm $\operatorname{size}\left(0.234^{*}\right)$.

Figure 1 shows a dendrogram for the existing diversity and similarities among 77 taro accessions were grouped into nine distinct clusters based on quantitative traits. The clustering pattern indicated that the number of accessions in each cluster varied from 1 to 31 . Cluster III comprising the maximum number of accessions accounting for about $40.26 \%$ (31 accessions) followed by cluster I which was contributed by $25.97 \%$ (20 accessions) of the total accessions whereas single accessions in each of the VII and IX clusters was found. Accessions in all cluster was predominantly characterized by plant size, leaf length: breadth ratio, leaf type (width), petiole: leaf length ratio, petiole type, sheath type, corm size, cormel size and yield/plant (Table 3). Similar results were also observed by (11) and (5). Most of the accessions collected from different regions were placed in all cluster except for cluster VII and IX in which only one accession was found in each cluster from different region.

Due to geographical diversity they may be placed in different cluster and indicates that they are not genetically identical with each other. However, accession no. 58 (C-6-92) placed in cluster VII had exhibited large leaf width, corm size, cormel size, high yield/plant and green petiole colour top $1 / 3$ of the length as well as petiole color middle of the length. While accession no. 35 (C-62) had low leaf width, corm size, cormel size, high yield/plant as compared to accession no. 35 (C-62) but petiole colour top $1 / 3$ of the length and petiole color middle of the length had exhibited purple green. Wide range of genetic variability were observed for morphophysiological characters like leaf arrangement, lamina orientation, leaf margin, leaf margin colour, leaf colour upper (U), leaf colour lower (L), sinus colour, vein colour upper, vein colour lower, petiole colour top $1 / 3$ of the length, petiole colour middle of the length, petiole colour base of the length, leaf sheath pattern and leaf sheath colour whereas, no variation were observed for traits viz; leaf variegation and floral formation. Maximum frequency distribution exhibited $94.81 \%$ representing 73 accessions for traits leaf margin having Entire (Em) margin followed by leaf colour lower (L) $93.51 \%$ that represent 72 accessions which is characterized by light green.

For the character leaf sheath colour; $76.62 \%$ of the accessions were exhibited green followed by $11.69 \%$ purple colour. Out of 77 accessions only eight superior lines viz, (C29, UP-1, UP-3, C-1-92,C-6-92, White Gauria (LC), Jhingri and Shri Palavi (NC) were selected at 10 per cent selection intensity pertaining green petiole color and recorded high cormel size as well as yield/plant as compared to non-green petiole coloured accessions. Therefore, green petiole colour of selected accessions might have made contribution to the production of assimilates which were channelled to the economic part of the plant which having the greatest corm weight. Similar finding were corroborated by (5), (20) and (18). The aim of correlation studies in primarily to know the suitability of various characters responsible for survival of other traits (14). Plant size exhibited positive and highly significant correlation with petiole type $\left(0.296^{* *}\right)$ and yield/plant $\left(0.407^{* *}\right)$ while negative and highly significant correlation were found with Leaf length: Breadth Ratio ($\left.0.367^{* *}\right)$. 
Table.1 Frequency distribution of leaf characteristics of the Arvi accessions

\begin{tabular}{|c|c|c|c|c|}
\hline Sl. No. & Characters & Description Adopted & No. of accessions & Frequency $(\%)$ \\
\hline 1. & \multirow{2}{*}{$\begin{array}{l}\text { Leaf } \\
\text { arrangement }\end{array}$} & Clock Wise (C) & 8 & 10.39 \\
\hline 2 & & Anti-clock Wise (A) & 69 & 89.61 \\
\hline \multirow[t]{3}{*}{3.} & \multirow{3}{*}{$\begin{array}{l}\text { Lamina } \\
\text { orientation }\end{array}$} & Erect (E) & 22 & 28.57 \\
\hline & & Droopy (DI) & 52 & 67.53 \\
\hline & & Cup shaped (CI) & 3 & 3.9 \\
\hline \multirow[t]{2}{*}{4.} & \multirow[t]{2}{*}{ Leaf margin } & Entire (Em) & 73 & 94.81 \\
\hline & & Undulate (Un) & 4 & 5.19 \\
\hline \multirow[t]{7}{*}{5.} & \multirow{7}{*}{$\begin{array}{l}\text { Leaf margin } \\
\text { colour }\end{array}$} & Green & 15 & 19.48 \\
\hline & & Light green & 19 & 24.68 \\
\hline & & Dark green & 11 & 14.29 \\
\hline & & Purplish green & 1 & 1.3 \\
\hline & & Purple & 23 & 29.87 \\
\hline & & Yellow & 1 & 1.3 \\
\hline & & Green Red & 7 & 9.09 \\
\hline \multirow[t]{3}{*}{6.} & \multirow{3}{*}{$\begin{array}{l}\text { Leaf colour } \\
\text { upper }(\mathrm{U})\end{array}$} & Green & 17 & 22.08 \\
\hline & & Dark green & 59 & 76.62 \\
\hline & & Purplish green & 1 & 1.3 \\
\hline \multirow[t]{5}{*}{7.} & \multirow{5}{*}{$\begin{array}{l}\text { Leaf colour } \\
\text { lower }(\mathrm{L})\end{array}$} & Green & 0 & 0 \\
\hline & & Light green & 72 & 93.51 \\
\hline & & Blue green & 2 & 2.6 \\
\hline & & Blue & 2 & 2.6 \\
\hline & & Purplish green & 1 & 1.3 \\
\hline \multirow[t]{5}{*}{8.} & \multirow[t]{5}{*}{ Sinus colour } & Green & 0 & 0 \\
\hline & & Light green & 66 & 85.71 \\
\hline & & Dark green & 1 & 1.3 \\
\hline & & Purplish green & 9 & 11.69 \\
\hline & & Purple White & 1 & 1.3 \\
\hline \multirow[t]{2}{*}{9.} & \multirow{2}{*}{$\begin{array}{l}\text { Leaf } \\
\text { variegation }\end{array}$} & Present & 77 & 100 \\
\hline & & Absent & 0 & 0 \\
\hline \multirow[t]{3}{*}{10.} & \multirow{3}{*}{$\begin{array}{l}\text { Vein colour } \\
\text { upper }\end{array}$} & Green & 13 & 16.88 \\
\hline & & Dark green & 60 & 77.92 \\
\hline & & Light green & 4 & 5.19 \\
\hline \multirow[t]{5}{*}{11.} & \multirow{5}{*}{$\begin{array}{l}\text { Vein colour } \\
\text { lower }\end{array}$} & Green & 1 & 1.3 \\
\hline & & Light green & 57 & 74.03 \\
\hline & & Dark green & 12 & 15.58 \\
\hline & & Purplish green & 2 & 2.6 \\
\hline & & Blue green & 5 & 6.49 \\
\hline
\end{tabular}


Table.2 Frequency distribution of leaf sheath, petiole and Flower characteristics of the Arvi

\begin{tabular}{|c|c|c|c|c|}
\hline Sl. No. & Characters & Description Adopted & $\begin{array}{c}\text { No. of } \\
\text { accessions }\end{array}$ & $\begin{array}{l}\text { Frequency } \\
(\%)\end{array}$ \\
\hline \multirow[t]{6}{*}{1.} & \multirow{6}{*}{$\begin{array}{l}\text { Petiole colour Top } 1 / 3 \text { of } \\
\text { the length }\end{array}$} & Light green & 2 & 2.60 \\
\hline & & Dark green & 1 & 1.30 \\
\hline & & Green & 52 & 67.53 \\
\hline & & Purplish & 7 & 9.09 \\
\hline & & Purplish green & 10 & 12.99 \\
\hline & & Blue & 5 & 6.49 \\
\hline \multirow[t]{6}{*}{2.} & \multirow{6}{*}{$\begin{array}{l}\text { Petiole colour middle of } \\
\text { the length }\end{array}$} & Light green & 2 & 2.60 \\
\hline & & Dark green & 1 & 1.30 \\
\hline & & Purplish green & 7 & 9.09 \\
\hline & & Green & 56 & 72.73 \\
\hline & & Purplish & 8 & 10.39 \\
\hline & & Blue & 3 & 3.90 \\
\hline \multirow[t]{6}{*}{3.} & \multirow{6}{*}{$\begin{array}{l}\text { Petiole colour base of the } \\
\text { length }\end{array}$} & Light green & 1 & 1.30 \\
\hline & & Green & 68 & 88.31 \\
\hline & & Dark green & 1 & 1.30 \\
\hline & & Purplish & 2 & 2.60 \\
\hline & & Purplish green & 2 & 2.60 \\
\hline & & Blue & 3 & 3.90 \\
\hline \multirow[t]{2}{*}{4.} & \multirow[t]{2}{*}{ Leaf sheath pattern } & Closed (Co) & 18 & 23.38 \\
\hline & & Open $(\mathrm{O})$ & 59 & 76.62 \\
\hline \multirow[t]{6}{*}{5.} & \multirow[t]{6}{*}{ Leaf sheath colour } & Green & 59 & 76.62 \\
\hline & & Light green & 1 & 1.30 \\
\hline & & Purplish green & 3 & 3.90 \\
\hline & & Dark green & 1 & 1.30 \\
\hline & & Purple & 9 & 11.69 \\
\hline & & Blue & 4 & 5.19 \\
\hline \multirow[t]{2}{*}{6.} & \multirow[t]{2}{*}{ Flower formation } & Flowering $(\mathrm{F})$ & 21 & 27.27 \\
\hline & & Non-flowering (NF) & 56 & 72.73 \\
\hline \multirow[t]{4}{*}{7.} & Seed formation & Absent (Nil) & 0 & 0.00 \\
\hline & \multirow[t]{3}{*}{ Maturity } & Early (EM) & 63 & 81.82 \\
\hline & & Normal (NM) & 14 & 18.18 \\
\hline & & Late (LM) & 0 & 0.00 \\
\hline
\end{tabular}


Table.3 Selection of superior lines by combination of different quantitative traits at 10 per cent selection intensity

\begin{tabular}{|c|c|c|c|c|c|c|c|c|c|c|c|}
\hline $\begin{array}{l}\text { Sl. } \\
\text { No. }\end{array}$ & $\begin{array}{l}\text { Access } \\
\text { ion No. }\end{array}$ & $\begin{array}{c}\text { Name of } \\
\text { accessions }\end{array}$ & $\begin{array}{c}\text { Plant } \\
\operatorname{size}(\mathrm{cm})\end{array}$ & $\begin{array}{c}\text { Leaf } \\
\text { length } \\
\text { :Breadth } \\
\text { Ratio }\end{array}$ & $\begin{array}{l}\text { Leaf type } \\
\text { (Width) } \\
\text { (cm) }\end{array}$ & $\begin{array}{c}\text { Petiole: } \\
\text { leaf } \\
\text { length } \\
\text { ratio }\end{array}$ & $\begin{array}{l}\text { Petiole type } \\
\quad(\mathrm{cm})\end{array}$ & $\begin{array}{c}\text { Sheath } \\
\text { type }(\mathrm{cm})\end{array}$ & $\begin{array}{c}\text { Corm } \\
\operatorname{size}(\mathrm{cm})\end{array}$ & $\begin{array}{c}\text { Cormel } \\
\text { Size }(\mathbf{c m})\end{array}$ & $\begin{array}{c}\text { Yield/plant } \\
\text { (kg) }\end{array}$ \\
\hline 1. & 29 & C-29 & 72.66 & 1.38 & 23.66 & 0.96 & 31.33 & 17.00 & 6.33 & 8.00 & 0.40 \\
\hline 2. & 40 & UP-1 & 71.66 & 1.32 & 27.33 & 0.84 & 30.16 & 17.00 & 5.50 & 7.50 & 0.15 \\
\hline 3. & 42 & UP-3 & 75.00 & 1.13 & 28.33 & 1.18 & 37.66 & 17.00 & 6.16 & 9.00 & 0.10 \\
\hline 4. & 46 & C-1-92 & 68.33 & 1.49 & 17.66 & 1.33 & 35.00 & 18.33 & 5.16 & 11.00 & 0.15 \\
\hline 5. & 58 & C-6-92 & 89.66 & 1.27 & 28.33 & 1.14 & 41.16 & 22.50 & 9.33 & 9.30 & 0.33 \\
\hline 6. & 59 & $\begin{array}{l}\text { White Gauria } \\
\text { (LC) }\end{array}$ & 80.33 & 1.23 & 29.16 & 0.92 & 33.16 & 24.12 & 9.00 & 9.30 & 0.13 \\
\hline 7. & 60 & Jhingri & 83.33 & 1.26 & 30.33 & 0.88 & 33.66 & 23.00 & 9.33 & 8.00 & 0.28 \\
\hline 8. & 76 & Shri Palavi (NC) & 85.00 & 1.14 & 30.33 & 0.91 & 31.66 & 26.00 & 6.00 & 7.30 & 0.34 \\
\hline \multicolumn{3}{|r|}{ Mean } & 61.44 & 1.39 & 21.94 & 0.89 & 26.22 & 15.80 & 7.03 & 7.08 & 0.30 \\
\hline \multicolumn{3}{|c|}{ Range limit } & $70.00-95.00$ & $0.81-2.73$ & $12.83-38.66$ & $0.35-1.40$ & $30.00-45.00$ & $14.00-28.33$ & $5.00-10.33$ & $7.00-15.00$ & $0.20-0.60$ \\
\hline
\end{tabular}

Table.4 Correlation coefficient among qualitative traits of the taro accessions

\begin{tabular}{|c|c|c|c|c|c|c|c|c|c|}
\hline Traits & $\begin{array}{c}\text { Plant } \\
\operatorname{size}(\mathbf{c m})\end{array}$ & $\begin{array}{c}\text { Leaf length } \\
\text { :Breadth } \\
\text { Ratio }\end{array}$ & $\begin{array}{c}\text { Leaf type } \\
\text { (Width) } \\
\text { (cm) }\end{array}$ & $\begin{array}{l}\text { Petiole: leaf } \\
\text { length ratio }\end{array}$ & $\begin{array}{c}\text { Petiole } \\
\text { type }(\mathbf{c m})\end{array}$ & $\begin{array}{l}\text { Sheath } \\
\text { type }(\mathrm{cm})\end{array}$ & $\begin{array}{c}\text { Corm } \\
\operatorname{size}(\mathbf{c m})\end{array}$ & $\begin{array}{c}\text { Cormel } \\
\text { Size }(\mathrm{cm})\end{array}$ & $\begin{array}{l}\text { Yield/plant } \\
\text { (kg) }\end{array}$ \\
\hline Plant size(cm) & 1.000 & $-0.367^{* *}$ & 0.185 & $-0.267^{*}$ & $0.296^{* *}$ & $0.293^{*}$ & $-0.289^{*}$ & 0.147 & $0.407^{* *}$ \\
\hline $\begin{array}{l}\text { Leaf length :Breadth } \\
\text { Ratio }\end{array}$ & & 1.000 & $-0.388^{* *}$ & 0.113 & $-0.297^{* *}$ & $0.253^{*}$ & $0.308^{* *}$ & $-0.289^{*}$ & 0.200 \\
\hline Leaf type (Width) (cm) & & & 1.000 & $-0.357^{* *}$ & 0.203 & $-0.277^{*}$ & 0.218 & $0.231^{*}$ & $0.292^{*}$ \\
\hline Petiole: leaf length ratio & & & & 1.000 & $-0.344^{* *}$ & 0.184 & $-0.254^{*}$ & $0.265^{*}$ & $0.259^{*}$ \\
\hline Petiole type $(\mathrm{cm})$ & & & & & 1.000 & $-0.353^{* *}$ & 0.117 & $-0.265^{*}$ & $0.277^{*}$ \\
\hline Sheath type(cm) & & & & & & 1.000 & $-0.368^{* *}$ & $0.234^{*}$ & $-0.295^{*}$ \\
\hline Corm size $(\mathrm{cm})$ & & & & & & & 1.000 & $-0.361^{* *}$ & $0.286^{*}$ \\
\hline Cormel Size(cm) & & & & & & & & 1.000 & $0.385^{* *}$ \\
\hline Yield/plant (kg) & & & & & & & & & 1.000 \\
\hline
\end{tabular}

* Significant at $\mathrm{P}=0.05 \quad * *$ Significant at $\mathrm{P}=0.01$ 
Int.J.Curr.Microbiol.App.Sci (2020) 9(6): 3551-3560

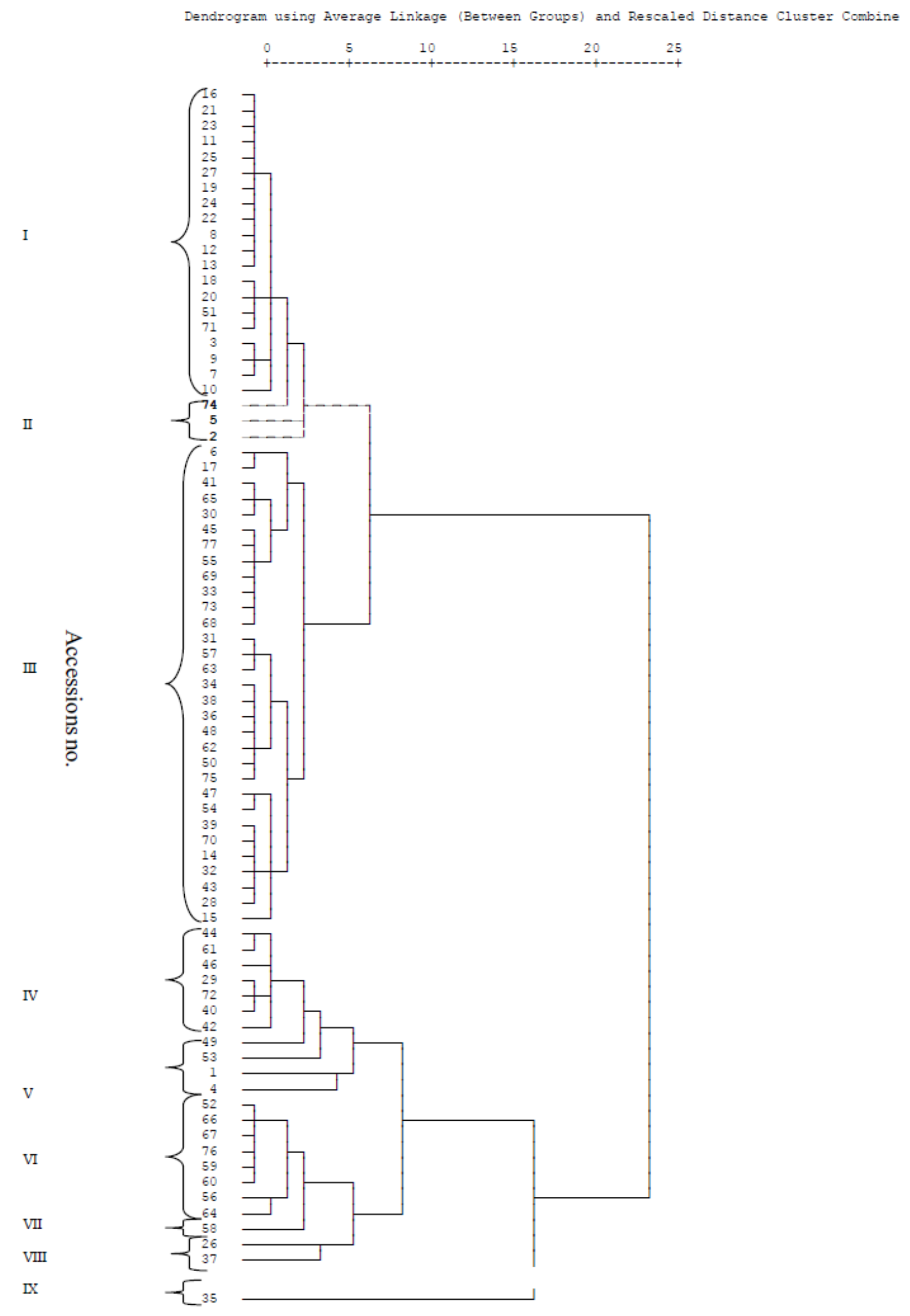

Figure.1 Dendrogram showing hierarchical clusters of 77 Taro Genotypes (UPGMA) based on quantitative characters 
Similarly leaf type had also exhibited significant and positive correlation with cormel size $\left(0.231^{*}\right)$ as well as yield/plant $\left(0.292^{*}\right)$. Petiole: leaf length ratio had positive and significant correlation with yield/plant $\left(0.259^{*}\right)$ whereas negative and highly significant correlation was found with Petiole type $\left(-0.344^{* *}\right)$.

Corm size recorded positive and highly significant correlation with yield/plant $\left(0.385^{* *}\right)$. Indicating that selection based on these traits may be effective for further improvement program of taro. Similar finding have been reported by (9), (15), (7), (12) and (4).

The cluster analysis indicates the extent of diversity that is practical for use to breeders (17). Most of the accessions collected from different regions were placed in all cluster except for cluster VII and IX in which only one accession was found in each cluster from different region. Due to geographical diversity they may be placed in different cluster and indicates that they are not genetically identical with each other.

However, accession no. 58 (C-6-92) placed in cluster VII had exhibited large leaf width, corm size, cormel size, high yield/plant and green petiole colour top $1 / 3$ of the length as well as petiole color middle of the length. While accession no. 35 (C-62) had low leaf width, corm size, cormel size, high yield/plant as compared to accession no. 35 (C-62) but petiole colour top $1 / 3$ of the length and petiole color middle of the length had exhibited purple green. These results suggest that the geographical origin of the taro cultivars does not bear any relationship with the morphophysiological characterization. This variation may also be associated with mutations and intensive selection by isolated human communities in diverse environments, followed by continuous vegetative propagation which resulted in the phenotypic diversity. Similar finding reported by (11), (21), (1), (3) and (19). The variation between the cultivars may be due to the heterogeneous nature of the plant according to (10) and (8) may be due to large variation in chromosome structure and number leading to the morphophysiological differences among the cultivars.

In the present investigation it can be concluded that morph-physiological characterization was useful for identifying variations among the accessions. Eight accessions viz; C-29, UP-1, UP-3, C-1-92,C6-92, White Gauria (LC), Jhingri and Shri Palavi (NC) were selected based on 10 per cent selection intensity and possess desirable characters such as earliness and yield which could be exploited for further breeding programme and conservation of plant genetic resources as core collection.

\section{References}

1. Ahmad, Z., Ajmal S.U., Munir M., Zubair, M. and Masood, M.S. (2008). Genetic diversity for morpho-genetic traits in barley germplasm. Pakistan Journal of Botany. 40: 1217-1224.

2. Akwee, P.E., Netondo, G., Kataka, J.A., Palapala, V.A. (2015). A critical review of the role of taro (Colocasia esculenta (L.) Schott) to food security: A comparative analysis of Kenya and Pacific Island taro germplasm. Scientia Agriculturae.9: 101108.

3. Ali, Y., Atta, M., Akhter, J., Monneveux, P. and Lateef, Z. (2008). Genetic variability, association and diversity studies in wheat (Triticum aestivum L.) germplasm. Pakistan Journal of Botany. 40: 2087-2097.

4. Bammite, Damigou, Matthews, Peter, J., Dagnon, Dodzi, Y., Agbogan Akouèthê, Odah Komi, Dansi Alexandre and Tozo Koffi. (2018). Agro morpho-physiological characterization of taro (Colocasia esculenta) and yautia (Xanthosoma mafaffa) in Togo. West Africa African Journal of Agricultural Research. 13(18):934-945. 
5. Boampong, R., Aboagye, L.M., Nyadanu, D. and Esilfie, M. (2018). Agro morphophysiological characterization of some taro (Colocasia esculenta (L.) Schott.) germplasms in Ghana. Journal of Plant Breeding and Crop Science.; 10(8):191- 202.

6. Bown, D. (2000). Aroids Plants of the Arum family. second edition. Timber Press, Portland, Oregon.

7. Cheema, D.S., Singh, H., Dhatt, A.S., Sidhu, A.S. and Garg, N. (2007). Studies on genetic variability and correlation for yield and quality traits in Arvi (Colocasia esculenta (L.) Schott). Acta Horticulturae. 75(2): 255260.

8. Ivancic, A. and Lebot, V. (2000). The Genetics and Breeding of Taro. Series Reperes. CIRAD: Montpellier, France. 194.

9. Mehta, J.L., Bendale, V.W., Bhawe SG, Saindane AK and Pethe UB. (2003). Correlation and path coefficient analysis in taro. Journal of Root Crops. 29(2): 32-35.

10. Morton, J. Cocoyams (1972). (Xanthosoma caracu, $\mathrm{X}$. atrovirens and $\mathrm{X}$. nigrum): Ancient root-and-leaf vegetables, gaining in economic importance. Florida State Sorticultura Society. 85- 94.

11. Mwenye, O.J. (2009). Genetic diversity analysis and nutritional assessment of cocoyam genotypes in Malawi. M.Sc. thesis submitted to university of the free state Bloemfontein, South Africa.

12. Paul, K.K., Bari, M.A., Islam, S.M.S. and Debnath, S.C. (2014). Genotypic and phenotypic correlation coefficient studies for taro (Colocasia esculenta (L.) Schott.). Bangladesh Journal of Botany. 43(1): 113117.

13. Quach, M.L., Melton, L.D., Harris, P.J., Burdon, J.N., Smith, B.G. (2003). Cell wall compositions of raw and cooked corms of taro (Colocasia esculenta). Journal of the Science of Food and Agriculture. 81:311-
318.

14. Searle, S.R.( 1965). The value of indirect selection. I. Mass selection. Biometrics.; 21: 682-708.

15. Singh, H.K., Gupta, S. and Singh, H.K. (2006). Correlation of quantitative characters contributing corm yield in colocasia. Haryana Journal of Horticultural Sciences. 35(1-2):138-139.

16. Srinivas, T., Nedunchezhiyan, M. and Misra, R.S.(2012). Statistics of aroids and yams in India. In: Marketing System of Aroids and Yams in India. CTCRI, Sreekariyam, Kerala, India pp. 8-13.

17. Sultana, T., Ghafoor, A. and Ashraf, M. (2006). Geographic pattern of diversity of cultivated lentil germplasm collected from Pallistanas assessed by protein assays. Acta Biologica Cracoviensia, Series Botanica Poland. 48:77-84.

18. Tewodros, M.B. (2013). Morphoagronomical characterization of Taro (Colocasia esculenta) accessions in Ethiopia. Plant. 1(1):1-9.

19. Vinutha, K.B., Devi, A.A. and Sreekumar, J. (2015). Morpho-physiological characterization of above ground characters of taro (Colocasia esculenta (L.) Schott.) accessions from North East India. Journal of Root Crops.; 41(1):3-11.

20. Yared D. (2007). Studies on indigenous production and evaluation of landrace taro clones (Colocasia esculenta (L.) Schott) at Dalbo watershed, Wolaita, South Ethiopia, MSc. Thesis, presented to School of Graduate Studies, Hawassa University, Awassa.

21. Zubair, M., Ajmal, S.U., Anwar, M. and Haqqani, M. (2007). Multivariate analysis for quantitative traits in mungbean (Vigna radiata (L.) Wilczek). Pakistan Journal of Botany. 39: 103-113.

\section{How to cite this article:}

Choudhary, A. K., S. B. Mishra, V. K. Choudhary, Shanti Bhushan and Singh, A. K. 2020. Morpho-Physiological Diversity in Arvi (Colocasia esculenta (L.) Schott. Var. Antiquorum). Int.J.Curr.Microbiol.App.Sci. 9(06): 3551-3560. doi: https://doi.org/10.20546/ijcmas.2020.906.418 